\title{
Concentration of Endogenous Secretory Receptor for Advanced Glycation End Products and Matrix Gla Protein in Controlled and Uncontrolled Type 2 Diabetes Mellitus Patients
}

\author{
Dwi Yuniati Daulay ${ }^{1,2, *}$, Suryani As'ad ${ }^{1}$, Ali Aspar Mappahya ${ }^{1}$, Andi Wijaya $^{1,3}$ \\ ${ }^{1}$ Postgraduate Program in Clinical Biochemistry, Hasanuddin University, Jl. Perintis Kemerdekaan Km.10, Makassar, Indonesia \\ ${ }^{2}$ Prodia Clinical Laboratory, Jl. Kramat Raya No.150, Jakarta, Indonesia \\ ${ }^{3}$ Prodia Clinical Laboratory, Jl. Cisangkuy No.2, Bandung, Indonesia \\ *Corresponding author. E-mail: dwi_daulay@yahoo.com
}

\section{Abstract}

B

ACKGROUND: Advanced glycation end products (AGE) and their receptor (RAGE) system play an important role in the development of diabetic vascular complications. Recently, an endogenous secretory RAGE (esRAGE) has been identified as a novel splice variant, which lacks the transmembrane domain and is secreted in human sera. Interestingly, it was reported that esRAGE binds AGE ligands and neutralizes AGE actions. Many studies have reported that diabetes mellitus correlates with vascular calcification event and increases progressively in uncontrolled diabetes. Matrix Gla Protein (MGP) is known to act as an inhibitor in vascular calcification. The aim of this study was to observe progress of vascular calcification in uncontrolled diabetes patient by biochemical markers MGP as inhibitor in vascular calcification, via mechanism of AGEs.

METHODS: This study was an observational study with cross sectional design on adult type 2 diabetic male patients who were defined by the 2011 Indonesian diabetes mellitus consensus criteria.

RESULTS: The results of this study showed that there was a positive significant correlation between esRAGE and $\mathrm{HbA} 1 \mathrm{C}$ ( $\mathrm{r}=0.651, p=0.009)$, and negative correlation between MGP and $\operatorname{HbA1C}(\mathrm{r}=-0.465, p=0.081)$ in controlled diabetes group. In uncontrolled diabetes group there was a positive significant correlation between MGP and $\mathrm{HbA} 1 \mathrm{C}(\mathrm{r}=0.350, p=0.023)$, despite the fact esRAGE showed no significant correlation with HbA1C. There was no significant difference in level of esRAGE and MGP in controlled and uncontrolled diabetes group, but MGP

\section{Abstrak}

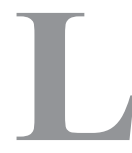

ATAR BELAKANG: Advanced glycation end products (AGE) dan reseptornya (RAGE) berperan penting dalam perkembangan komplikasi pada diabetes. Penelitian terkini mendapatkan bahwa endogenous secretory RAGE (esRAGE) merupakan varian baru dari RAGE akibat mutasi sehingga kehilangan area transmembrannya, sehingga bisa ditemukan di serum. Menariknya, telah ditemukan bahwa esRAGE mengikat ligan dari AGE dan menetralkan aktivitas dari AGE. Banyak studi melaporkan bahwa diabetes melitus berhubungan dengan kejadian kalsifikasi vaskular, dan progresifitasnya meningkat pada diabetes yang tidak terkontrol. Matrix Gla Protein (MGP) diketahui merupakan molekul yang bertindak sebagai inhibititor kalsifikasi vaskular. Tujuan dari penelitian ini adalah untuk mengetahui progresifitas kalsifikasi vaskular pada pasien diabetes melitus yang tidak terkontrol melalui MGP sebagai inhibitor kalsifikasi, melalui mekanisme yang melibatkan AGE.

METODE: Penelitian ini merupakan studi observasi dengan desain potong lintang pada pria dewasa dengan diabetes melitus tipe 2 sesuai kriteria konsensus diabetes melitus Indonesia 2011.

HASIL: Hasil dari penelitian ini menunjukkan bahwa ada korelasi positif yang signifikan antara esRAGE and HbA1C $(\mathrm{r}=0,651, p=0,009)$, dan korelasi negatif antara MGP and $\operatorname{HbA1C}(\mathrm{r}=-0,465, p=0,081)$ pada kelompok diabetes terkontrol. Pada kelompok yang tidak terkontrol, ada korelasi positif yang signifikan antara MGP and $\mathrm{HbA1C}$ ( $\mathrm{r}=0,350, p=0,023)$, sementara esRAGE tidak menunjukkan adanya korelasi yang signifikan dengan HbAlc. Tidak 
showed lower level in uncontrolled diabetes group, contrary to esRAGE that had higher concentration.

CONCLUSION: In diabetes condition, complications of vascular calcification are caused by the mechanism of increased AGE formation represented by esRAGE. In diabetes control it is very important to keep the blood vessels from complications caused by vascular calcification.

KEYWORDS: type 2 diabetes mellitus, vascular calcification, esRAGE, MGP, HbA1C

Indones Biomed J. 2013; 5(1): 31-6 ditemukan adanya perbedaan yang signifikan kadar esRAGE dan MGP baik pada kelompok diabetes terkontrol maupun tidak terkontrol, tetapi kadar MGP ditemukan lebih rendah pada kelompok diabetes tidak terkontrol, sebaliknya kadar esRAGE ditemukan lebih tinggi.

KESIMPULAN: Pada kondisi diabetes, komplikasi kalsifikasi vaskular salah satunya disebabkan mekanisme peningkatan AGE yang direpresentasikan oleh esRAGE. Pada kondisi diabetes, pengontrolan kadar gula darah sangat diperlukan untuk menjaga pembuluh darah dari komplikasi yang disebabkan oleh kalsifikasi vaskular.

KATA KUNCI: diabetes melitus tipe 2, kalsifikasi vaskular, esRAGE, MGP, HbA1C

\section{Introduction}

According to the WHO survey, Indonesia ranks fourth of all countries in the world in the number of patients with diabetes mellitus (DM) with a prevalence of about $8.6 \%$ of the total population. Another fact is the data from the Ministry of Health, which state that the number of inpatients and outpatients in hospitals with diabetes is ranked first of all endocrine diseases. Worldwide, the incidence of type 2 diabetes mellitus (T2DM) is increasing rapidly. In Indonesia, WHO estimates the increasing number of people with diabetes may rise from 8.4 million in 2000 may rise to about 21.3 million by 2030.(1)

Two main subtypes of diabetes are type 1 and T2DM. T2DM comprises about 80-90\% of all cases.(2) Diabetic patients may suffer a number of debilitating complications such as retinopathy, nephropathy, neuropathy, and atherosclerosis resulting in cardiovascular, cerebrovascular, or peripheral vascular disease. These diabetic complications lead to huge economic and psychosocial consequences.(3)

Diabetes mellitus, particularly T2DM, is associated with a markedly increased risk of cardiovascular events mainly due to premature and extensive atherosclerosis. (2)

There are several mechanisms that underlie the occurrence of complications in diabetes, one of which is the formation of advanced glycation end products (AGE). By generating oxidative stress, AGE encourages vasoconstriction, inflammatory and prothrombotic gene expression, which would result in endothelial dysfunction. (4) This causes damage to the retina, the nephrons, the central and peripheral nervous system, as well as atherosclerosis. (5) Some receptors for AGE have been found, one of which is the receptor for AGE (RAGE), which is a key component of the amplification of the inflammatory cascade and tissue injury constantly(4). RAGE has an isoform called soluble RAGE (sRAGE), Endogenous secretory RAGE (es-RAGE), a splice variant of one of the naturally occurring secretory forms, is known to carry all the extracellular domains but lacks the transmembrane and cytoplasmic domains. Secreted es-RAGE in the extracellular space is thought to act as a decoy receptor that binds AGEs and results in reducing the activity of intercellular signal pathways via RAGE.(6) Atherosclerotic disease is characterized by the accumulation of lipid material in the arterial wall resulting from autoimmune and inflammatory mechanisms. More than $90 \%$ of these fatty plaques undergo calcification. Some studies have demonstrated a direct relationship between the degree of calcification of the atherosclerotic plaque and mortality due to cardiovascular events.(7)

Vascular calcification, long a result of passive degeneration, involves a complex, regulated process of biomineralization resembling osteogenesis. Evidence indicates that proteins controlling bone mineralization are also involved in the regulation of vascular calcification. Vascular calcification is exacerbated in certain clinical entities, including diabetes, menopause, and osteoporosis.

In patients with diabetes, arterial calcification is associated with an increased risk of cardiovascular complications.(9) In sub-sample of the population-based Framingham Offspring Study, subjects with insulin resistance or impaired fasting glucose (IFG) / impaired glucose tolerance (IGT) and T2DM had an increased burden of coronary artery subclinical atherosclerosis, shown by using Electron-Beam Computed Tomography(10). 
Recent data suggest that arterial calcifications occur as the result of an active, regulated process that involves inhibitors and promoters of vascular calcification. This idea is based partly on findings of high expression of bonerelated macromolecules, such as alkaline phosphatase, bone sialoprotein, bone Gla protein and osteoprotegerin as promoters of calcification in calcified areas of the arterial wall. Furthermore, direct evidence comes from gene knockout experiments of matrix Gla protein (MGP) and osteopontin-lacking mice, which develop extensive vascular calcification. $(11,12)$

MGP is inhibitor of vascular calcification involved in the development of DM complication, especially uncontrolled diabetes. This inspired us to study the difference of vascular calcification event between controlled and uncontrolled T2DM. The aim of this study was to observe the progress of vascular calcification in diabetic patients by mechanism of esRAGE, and biochemical marker MGP as inhibitor in vascular calcification among Indonesian T2DM male patients.

\section{Methods}

The study protocol was approved with ethical clearance obtained from the Health Research Ethics Committee Faculty of Medicine, University of Hasanuddin, Makassar, Indonesia. All participants signed written informed consent.

Sixty one T2DM male patients were enrolled in this cross sectional study. At the baseline examination, each participant completed a self administered questionnaire covering medical history, exercise, treatment for hypertension or diabetes, smoking habits, and alcohol intake. The questionnaire was checked by researcher at the screening. Subjects who were consuming steroid; or had been treated with anti-inflammatory drugs such as statins in the last 3 weeks; or had liver dysfunction, kidney dysfunction, fever and other acute inflammation were excluded from the study. Each subject was given explanation about the study and asked to sign informed consent prior to the commencement of the study.

All subjects were assessed after overnight fasting for at least 10 hours. The parameters of anthropometric measurements (height, weight, body mass index (BMI), waist circumference, and blood pressure) and the biochemical variables (fasting plasma glucose (FPG), estimated Glomerular Filtration Rate (eGFR), Alanine transaminase (ALT), glycated hemoglobin / hemoglobin $\mathrm{A} 1 \mathrm{c}(\mathrm{HbA1c}), \mathrm{MGP})$ were measured in all subjects.

\section{Assay of Biochemical Markers}

Blood specimen was collected by venipuncture in serum tubes $(10 \mathrm{~mL}$; BD Vacutainer Systems) and in sodium citrate $(10 \mathrm{~mL}$; BD Vacutainer Systems) and stored for 20 minutes at room temperature before centrifugation. Serum and plasma were sub-sampled in aliquots and frozen at $-20^{\circ} \mathrm{C}$.

Serum MGP concentrations were quantified with the kit from Biomedica (Vienna, Austria). The kit is based on the competitive enzyme-linked immunosorbent assay (ELISA) principle with antibodies against non-phosphorylated MGP coated on the microtiter plate.

Serum esRAGE concentrations were quantified with the kit from B-Bridge International Human esRAGE ELISA. The kit is based on the sandwich ELISA principle. This assay employs an antibody specific for human esRAGE coated on a 96-well plate.

All assays were performed according to manufacturers' instruction.

\section{Statistical Analysis}

Statistical analysis was performed with the SPSS 11.5 statistical software package. Univariate analysis was performed to calculate mean, maximum and minimum value and SD. Spearman correlation statistic was used to determine the correlation among the various variables. Significance levels were based on two-tailed tests.

\section{Results}

\section{Most of Subjects are poorly controlled DM}

Statistical tests in this study were performed on 61 subjects, which consisted of 17 subjects with controlled DM (HbA1c $<7 \%$ ) and 44 subjects with poorly controlled DM (HbAlc $>7 \%$ ). eGFR values for renal function and ALT values for liver function of the 61 subjects were within normal limits. General description of subject's baseline characteristics is shown in Table 1.

Table 1. Subjects' Baseline Characteristics.

\begin{tabular}{lcccc}
\hline \multicolumn{1}{c}{ Variables } & Min & Max & Mean & SD \\
\hline Age (years) & 36 & 63 & 53.40 & 6.70 \\
Clinical Variables & & & & \\
BMI & 14.90 & 33.50 & 23.71 & 3.18 \\
Biochemical Variables & & & & \\
FPG (mg/dl) & 55 & 294 & 143.50 & 50.50 \\
HbA1c (\%) & 5.10 & 12.60 & 8.30 & 1.90 \\
esRAGE (ng/ml) & 0.08 & 0.90 & 0.34 & 0.15 \\
MGP (nmol/) & 52,056 & 194,878 & 109,508 & 31,987 \\
\hline
\end{tabular}




\section{Correlation between HbA1c with esRAGE and MGP}

Table 2 shows the correlation between HbA1c and esRAGE and inhibitor of vascular calcification in controlled and uncontrolled T2DM groups. The trend is shown in Figure 1 and 2 .

Inhibitor of Vascular Calcification is lower in Uncontrolled T2DM Group

To see the difference in esRAGE and inhibitor of vascular calcification between controlled T2DM and uncontrolled T2DM groups, an independent t-test was done and the result showed the existence of differences, but not significant. The concentration of esRAGE in uncontrolled T2DM group was higher than that in controlled T2DM group, but in the contrary the concentration of MGP was lower in uncontrolled T2DM. These results are shown in Table 3.

Table 2. Correlation between HbA1c with esRAGE and MGP in controlled and uncontrolled T2DM groups.

\begin{tabular}{lcccc}
\hline & \multicolumn{2}{c}{$\begin{array}{c}\text { Controlled T2DM } \\
\text { Group }(\mathbf{n = 1 3})\end{array}$} & \multicolumn{2}{c}{$\begin{array}{c}\text { Uncontrolled T2DM } \\
\text { Group }(\mathbf{n = 4 0 )}\end{array}$} \\
\cline { 2 - 5 } Variable & \multicolumn{4}{c}{ HbA1c } \\
\cline { 2 - 5 } & $\mathrm{r}$ & $p$ & $\mathrm{r}$ & $p$ \\
\hline esRAGE & $0.651^{*}$ & 0.009 & 0.010 & 0.950 \\
MGP & $-0.465^{*}$ & 0.081 & $0.350^{*}$ & 0.023 \\
\hline
\end{tabular}

$*=$ significant at $p<0.05$

Table 3. T-test analysis of esRAGE and MGP in controlled and uncontrolled T2DM groups

\begin{tabular}{lccc}
\hline \multicolumn{1}{c}{ Variables } & $\begin{array}{c}\text { Controlled } \\
\text { T2DM Group }\end{array}$ & $\begin{array}{c}\text { Uncontrolled } \\
\text { T2DM Group }\end{array}$ & $\boldsymbol{p}$ \\
\hline esRAGE $(\mathrm{ng} / \mathrm{ml})$ & $0.309 \pm 0.104$ & $0.350 \pm 0.172$ & 0.584 \\
& & & \\
MGP (nmol/) & $112,170 \pm 26,155$ & $108,479 \pm 34,183$ & 0.426 \\
\hline
\end{tabular}

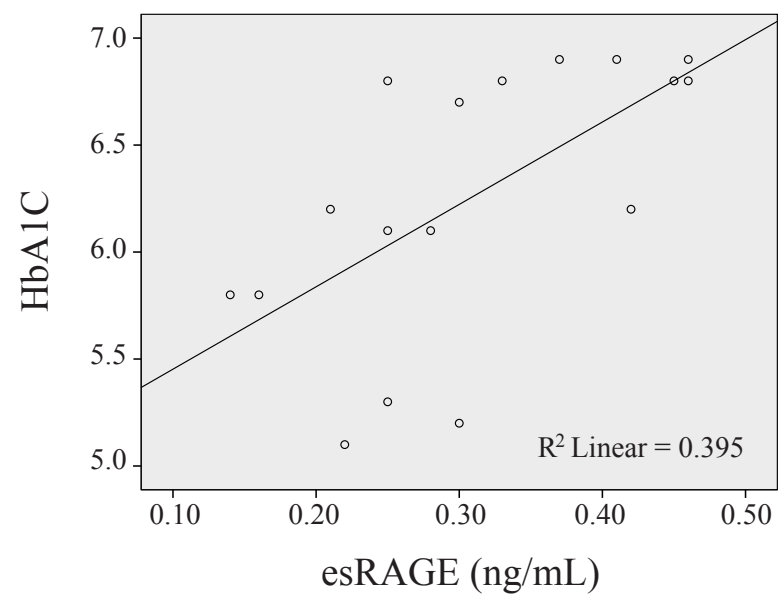

Figure 1. Plasma esRAGE according to the plasma HbA1C.

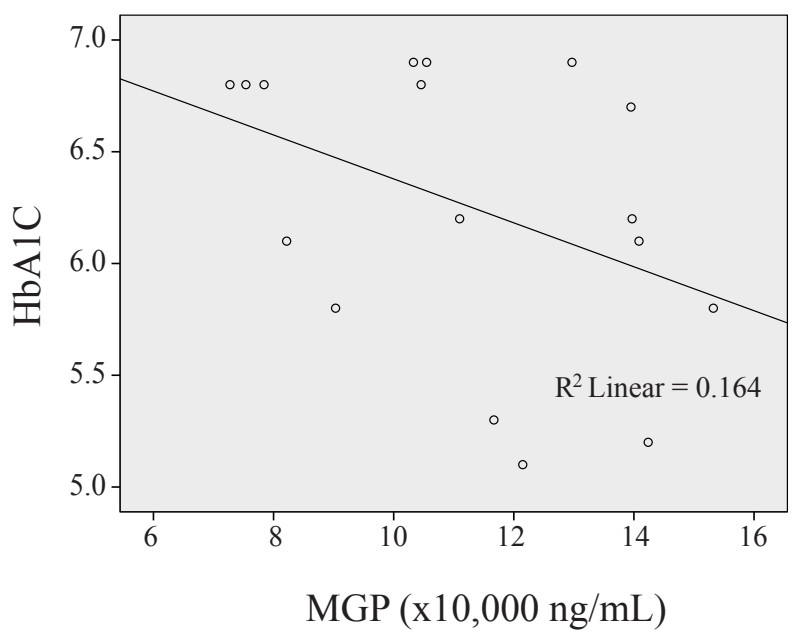

Figure 2. Plasma MGP according to the plasma HbA1C.

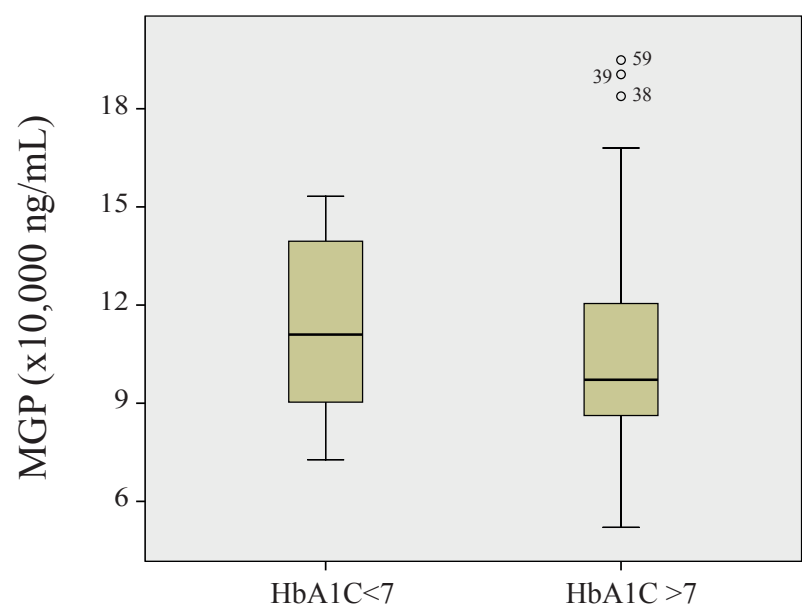

Figure 3. Comparison of serum levels of MGP among controlled and uncontrolled T2DM groups.

\section{Discussion}

The results of this study showed in controlled T2DM group there was a positive significant correlation between $\mathrm{HbAlc}$ with esRAGE levels, and there was no significant correlation in uncontrolled T2DM group, meaning that esRAGE was closely related to well-controlled diabetic condition.

The balance between the levels of RAGE ligands, RAGE and sRAGE may represent a dynamic system. It has been demonstrated that pathophysiological situations of DM enhance the expression of RAGE and its ligands. Inflammation increases the production and accumulation of AGEs, and subsequently leads to the increased activation of RAGE and further enhances the inflammatory state. The relationship between the up-regulation of RAGE/RAGE ligands and the level of 'protective' sRAGE levels is of obvious clinical interest. On the other hand, in vitro studies 
recently revealed that treatment of cells with High mobility group protein B1 (HMGB1) increased the formation of soluble cRAGE released in the supernatant. Similarly, a positive correlation between serum AGEs and sRAGE levels in non-diabetic subjects has been highlighted, suggesting that interaction of RAGE with its ligands enhances sRAGE synthesis. However, sRAGE has been shown to have a negative feedback on RAGE interaction with its ligands. Therefore it seems that sRAGE, RAGE and its ligands are three elements of a balance with positive and negative feedbacks which could be modified by pathophysiological situations. The precise mechanisms responsible for the fine balance between membrane-bound RAGE and its secreted/ cleaved soluble variant are currently unknown, and the elucidation of the mechanism(s) responsible for their regulation is an important biological question.(13) This study showed that in controlled T2DM group there was a negative correlation between $\mathrm{HbA1c}$ with MGP levels although not statistically significant, and the serum level of MGP as inhibitor of vascular calcification was lower in uncontrolled diabetes group although this difference was not statistically significant, it means that subjects with diabetes have a risk for vascular calcification.

Supporting this notion, recent reports have suggested a sequence of molecular events in vascular calcification beginning with the loss of expression by by vascular smooth muscle cells (VSMCs), of constitutive inhibitory proteins, and ending with expression by VSMCs and macrophages of chondrocytic, osteoblastic, and osteoclastic-associated proteins that orchestrate the calcification process.(14)

Vascular calcification is a consequence of tightly regulated processes that culminate in organized extracellular matrix deposition by osteoblast-like cells. These cells may be derived from stem cells or differentiation of existing cells, such as smooth muscle cells or pericytes. Several factors induce this transition, including bone morphogenetic proteins, oxidant stress, high phosphate levels, parathyroid hormone fragments, and vitamin D. Once the osteogenic phenotype is induced, cells gain a distinctive molecular fingerprint, marked by the transcription factor core binding factor 1. Alternatively, loss of inhibitors of mineralization, such as matrix carboxyglutamic acid Gla protein, fetuin, and osteopontin, also contribute to vascular calcification.

The result of this study also showed a positive significant correlation between HbAlc with MGP levels in uncontrolled T2DM group. Why are greater MGP levels in humans associated with diabetes and with an increased, rather than a decreased, risk of cardiovascular disease? One hypothesis is that increased serum MGP levels in uncontrolled T2DM is a "response" to rather than a "cause" of vascular calcification, perhaps in an attempt to regulate those processes. Another explanation is that the greater MGP levels are a result of decreased clearance of MGP, perhaps because of increased binding of MGP ligand.(15)

\section{Conclusion}

In diabetes condition, complication of vascular calcification are caused by the mechanism of increased AGE formation, represented by esRAGE. In diabetes control it is very important to keep the blood vessels from complication caused by vascular calcification.

\section{Acknowledgement}

We would like to thank the Prodia Education and Research Institute for the invaluable support to this study.

\section{References}

1. Pustaka Kedokteran [http://penyakitdalam.wordpress.com/]. Jakarta: Konsensus Pengelolaan dan Pencegahan Diabetes Melitus Tipe 2 di Indonesia [cited 2009 Oct 1]. Available from: http://penyakitdalam. files.wordpress.com/2009/11/konsensus-pengelolaan-danpencegahan-diabetes-melitus-tipe-2-di-indonesia-2006.pdf

2. Goldstein BJ, Muller-Wieland D. Type 2 Diabetes Principle and Practice. 2nd ed. London: Informa Healthcare; 2008.

3. Johnstone MT, Veves A. Diabetes and Cardiovascular Disease. 2nd ed. New Jersey: Humana Press ; 2005.

4. Goldin A, Beckman JA, Schmidt AM, Creager MA. Advanced Glycation End Products: Sparking the Development of Diabetic Vascular Injury. Circulation. 2006; 114: 597-605.

5. Stirban AO, Tschoepe D. Cardiovascular complications in diabetes: targets and intervensions. Diabetes Care. 2008; 31: 215-21.

6. Yamamoto M, Yamaguchi T, Yamauchi M, Sugimoto T. Low Serum Level of the Endogenous Secretory Receptor for Advanced Glycation End Products (esRAGE) Is a Risk Factor for Prevalent Vertebral Fractures Independent of Bone Mineral Density in Patients With Type 2 Diabetes. Diabetes Care. 2009: 32: 2263-2268.

7. Danilevicius CF, Lopes JB, Pereira RM. Bone Metabolism and Vascular Calcification. Braz J Med Biol Res. 2007; 40: 435-42.

8. Abedin M, Tintut Y, Demer LL. Vascular calcification: mechanism and clinical ramifications. Arterioscler Thromb Vasc Biol. 2004; 24: 1161-70.

9. Doherty T.M, Fitzpatrick LA, Inoue D, Qiao JH, Fishbein MC, Detrano $\mathrm{RC}$, et al. Molecular, endocrine, and genetic mechanisms of arterial calcification. Endocr Rev. 2004; 25: 629-72.

10. Meigs JB, Larson MG, D'Agoetino RB, Levy D, Clouse ME, Nathan $\mathrm{DM}$, et al. Coronary artery calcification in type 2 dabetes and insulin resistance: the Framingham offspring study. Diabetes Care. 2002; 25: 1313-9.

11. Olesen P, Nguyen K, Wogensen L, Ledet T, Rasmussen LM. Calcification of human vascular smooth muscle cells: associations with osteoprotegerin expression and acceleration by high-dose insulin. Am J Physiol Heart Circ Physiol. 2007; 292: H1058-64.

12. Secchiero P, Corallini F, Pandolfi A, Consoli A, Candido R, Fabris B, 
et al. An increase osteoprotegerin serum release characteristizes the early onset of diabetes mellitus and may contribute to endothelial cell dysfunction. Am J Pathol. 2006; 169: 2236-44.

13. Maillard-Lefebvre H, Boulanger E, Daroux M, Gaxatte C, Hudson BI, Lambert M. Soluble receptor for advanced glycation end products: a new biomarker in diagnosis and prognosis of chronic inflammatory diseases. Rheumatology. 2009; 48: 1190-6.

14. Tyson KL, Reynolds JL, McNair R, Zhang Q, Weissberg PL, Shanahan $\mathrm{CM}$. Osteo/chondrocytic transcription factors and their target genes exhibit distinct patterns of expression in human arterial calcification. Arterioscler Thromb Vasc Biol. 2006; 23: 489-94.

15. Browner WS, Lui L, Cummings SR. Associations of serum osteoprotegerin levels with diabetes, stroke, bone density, fractures, and mortality in elderly women. J Clin Endocrinol Metab. 2001; 86: 631-7. 